\title{
Effects of Mobile Assisted Language Learning on Developing Listening Skill to the Department of English Students in College of Education for Women at Al Iraqia University
}

\author{
Abeer Hadi Salih \\ Asst. Prof. Department of English Language/ College of Education for Women-Al Iraqia University / Baghdad -Iraq
}

\begin{abstract}
Many studies have described the use of mobile assisted language learning in language teaching and learning; yet, the number of studies in listening skill remains unsatisfactory. Few researchers appear to have considered how to use mobile learning devices to support pedagogical approach to develop academic listening skills. Several studies in the past, required learners to read from mobile phones rather than listening to audios. There were attempts to use computer technology integration into instruction; however, few were in mobile technology. The interest in research related to the impact of mobile assisted language learning on developing students' listening skills remains relatively low and consequently listening has been neglected. Thus, the current paper aims at exploring the effectiveness of mobile assisted language learning devices both as instructional tools and learning resources within and beyond classroom learning environments to develop language skills in particular listening sub-skills. The experimental design is pretest-experiment-post-test. To conduct the study two groups of experimental (30) and control (30) out of 60 second year students at Al Iraqia University/ college of education for women/ department of English were made. Both groups were taught the same material, but using different methods. The results of the post-test indicated that the use of mobile assisted language learning devices had impacts on developing experimental group's listening skills and outperformed the control group.
\end{abstract}

Keywords: effects, mobile, assisted, language, learning, developing, listening, skill

\section{Introduction}

\section{Problem of the Study}

Rapid proliferation of the technology leads to its widespread use in many areas of our lives especially education. Since its emergence, technology has been playing a crucial role in instruction processes. For decades, computer assisted language learning (CALL) has been used and integrated into teaching and learning languages. The advent of personal computers and the Internet as educational tools offers effective use of time and ease of access to educational materials for students and teachers alike. With the emergence of mobile assisted language learning (MALL) as extension or sub-branch of CALL, language pedagogy has drastically changed. Teaching and learning with mobile learning devices became easy for both teachers and learners. Fundamental changes in mobile device features and functions encouraged educators and scholars to explore more uses of these handheld devices in language pedagogy.

\subsection{Hypotheses:}

It is hypothesized that there is a significant difference between the results of the pre-test and post-test in the students' listening sub-skills developments after conducting the experiment.

\subsection{Aim of the Study:}

For the aim of this study, the researcher developed effective and authentic instructional materials and delivered on mobile assisted language learning devices (smartphones) when connected to the Internet through which accessing the platform on which learning materials were uploaded.

\subsection{Limits of the study:}

The researcher has chosen English language listening learning material as the subject matter and presented on Al iraqia university students/college of education which is a multi-media learning system. Considering the limited number of MALL studies focusing on listening, the current study tries to investigate the impact of using such devices on developing listening sub-skills of EFL learners. 


\subsection{Participants}

The participants were 60 second year undergraduate students who had (or nearly had) reached an intermediate level in terms of English proficiency at the Department of English in college of Education for women Al Iraqia University, (30) of whom as an experimental group and the other (30) as a control group who supposed to be between 18-20 years old and intermediate level of English language proficiency.

\subsection{Procedure}

The study uses pre and post-treatment tests in listening skills. In listening pre-and post-tests, the researchers administered and distributed test questions about listening sub-skills before and after the treatment during the course of learning of 15 weeks. The program is carried out by using smart mobile phones as MALL devices to present listening materials and it is shown on the Al Iraqia university course module website as platform which is a Multimedia system and learning management system.

\section{M-Learning}

It is the matter of debate whether m-learning is the advanced step of e-learning or a sophisticated device that integrates with e-learning. "M-Learning is a new and unique component of distance learning." (Caudill, 2007, p. 2) With the commencement of mobile learning in 2001, not many but some people knew about the concept of m-learning or, even, could imagine the capacities of mobile devices in learning (Attewell, 2005). The evolution of mobile learning is from electronic learning, which has developed from distance learning. E-and M-Learning are subdivisions of D-Learning (Cherian \& Williams, 2008). [M]-learning is a sub-set of e-learning movement (Chinnery, 2006: p.9). That is, they cannot be separated easily. However, in contrast with electronic learning, mobile learning is new in language instruction.

It is difficult to define mobile learning because it is a new and distinct educational format or a variety of e-learning. According to Traxler (2005: pp. 262-263) mobile learning is "... any educational provision where the sole or dominant technologies are handheld or palmtop devices." Technologies or mobiles can be instrumental or instructional tools in language instruction rather than instructors in themselves (Chinnery, 2006). In other words, they cannot replace the role of the teacher inside the classrooms.

\subsection{Advantages of MALL}

There is interesting literature about the advantages of mobile assisted language learning devices in education. With the emergence of m-learning technologies learning contexts have changed to anytime, anyplace learning; these advantages were on the top list by advocates of "online education" (Caudill, 2007, p.1). Learners no more need to restrict themselves to any location or sit on a desk computer. However, in entertaining places like restaurants, or even bus stations they can access studying materials and get in contact with instructors or classmates (Caudill, 2007). These tools are no longer restrict learners into four-wall classrooms (Chinnery, 2006). This unique feature of mobile devices results in many other advantages. For instance, Kennedy and Levy (2008) have reported that learners find learning languages with MALL applications and devices quite motivating due to their portability, accessibility, widespread ownership of certain mobile devices like mobile phones, wireless laptops, and media players. Begum (2011, pp. 110-111) states that among MALL devices in teaching and learning classrooms, mobile phones have many benefits such as: ubiquity, portability, pervasiveness, students' freedom, promoting learning, involving students in learning with a more relaxed and comfortable environment, enjoying classrooms, removing boredom in language teaching, increasing participation, reducing feeling shy, cost saving, promoting an interactive and virtual classroom, connecting to sophisticated Internet functions, wireless mobile learning, and accessing lessons anytime and anywhere. In addition, Sevari $(2012$, p. 19) believes that some of the virtues of cell phones in the education are advancement and augment of learners' comprehending of challenging concepts, completion of teachers' instructions, matching the needs and interests of students, enhancement of critical thinking skills, eloquent use of time and not to misspend the class time. Furthermore, Sevari thinks that the students' interest in using mobile phones and their cheap prices results to ease learning.

\subsection{Disadvantages of MALL}

Despite merits, MALL as an educational tool has some demerits. Many scholars and researchers come to agree on their small screen. For example, (Begum, 2011; Goundar, 2011; Chinnery, 2006; Thornton and Houser, 2005 \& Mehta, 2012) have raised this issue with mobile devices. For Begum (2011) and Goundar (2011) the conventional contents of language learning cannot be accommodated by cell phones due to their small screen sizes. 
Chinnery (2006) criticizes MALL devices for their tiny screen sizes and keyboarding problems because of one finger data entry. Other problematic factors are battery charge, battery life, restrict memory space, lack of teachers' training to arrange $\mathrm{m}$-learning activities through cell phones in the classroom, high costs for arranging language learning activities via sending SMS and data transmission, feeling uncomfortable in typing on the tiny keyboard, small keypads, reading SMS, word limitation, definite storage space, difficulty in utilizing mobile tools in noisy settings and communication failure owe to poor net connectivity, and teachers' difficulties in managing the students with cell phones (Begum, 2011; Mehta, 2012 \& Goundar, 2011). Along with these, there are other educational, social and personal disadvantages. Mobiles, inside classes, would be the source of destruction and interruption for students. For example, Sevari (2012: 21) states that mobile learning devices can have drawbacks such as: sending short messages during class period, transmitting and getting test responses, bothering others, putting much load of responsibility on the teacher, treating with educational troubles brought about forgetting to carry mobile phones, failure of learning mode, necessities, skills and interests of students, and delaying in sending and receiving messages due to network outages. Finally, regarding the pitfalls of mobile phones, Mtega, et al. (2012, p. 118) state that the costs related to downloading multimedia content was another limitation which restricted some participants especially students from using phones for learning purposes.

\section{Listening Skill}

Listening skill is defined as ".. the act of paying close attention to the conversation of another person (s) in order to obtain selectively verbal and nonverbal clues to behavior pattern." (Good, 1973, p. 43) In another definition, Lynch and Mendelsohn as cited in Schmitt (2002) believe that listening is an active process as speaking. Moreover Anderson \& Lynch, (2003, p. 4) perceive listening as "a reciprocal skill ... involves a multiplicity of skills".

\subsection{MALL and Listening}

For Helgesen (2003), "Listening is an active, purposeful process of making sense of what we hear"; however, it is sometimes thought to be a passive skill. In terms of listening skills, lecturers can design a platform on which students listen to texts by vocal service on their mobile phones. After that, they may complete quizzes on listening comprehension on the bases of the aural text (AL-Qudaimi, 2013, p.9). The study results by Azar and Nasiri (2014) on two groups of EFL Iranian learners who enrolled in conversation course to investigate the effectiveness of mobile assisted language learning on listening comprehension indicated that the experimental group who received cell-phone based audiobook instruction outperformed the control one.

\section{Data Analysis}

In order to test the proposed hypothesis (It is hypothesized that there is a significant difference between the results of the pre-test and post-test in the students' listening sub-skills developments after conducting the experiment); the two groups took 'pre-posttests' in listening sub-skills. The t-test results demonstrate a significant difference between the mean score (6.74) in the pretest and the mean score (8.06) in the posttest on the experimental students' listening sub-skills. Firstly, as shown in table 1 below, the Mean score in pre-test for experimental group is (6.74) whereas, this sum has been increased with the value of (1.32) and reached (8.06) in the post test. It shows a moderate significant difference between the two tests that leads to apply one sample t-test. As shown in the same table, the achieved t-test (4.936) is bigger than the t-table (2.042) with the degree of freedom (30), significance level $(0.05)$ and $p$-value $(0.000)$. Consequently, we reach the conclusion that there is significant difference between the two tests. That is to say, due to the effects of those (15) weeks treatment a significant change has been emerged in the mean of the tests that shows effectiveness of mobile assisted language learning devices on developing listening sub-skills. But with the control group as demonstrated in table 1, the mean score in pre-test is (7.50) whereas, this sum has been decreased with the value of (0.31) and reached (7.19). It does not show any significant difference between the two tests and does not lead to apply one sample t-test. Also, the achieved t-test $(0.527)$ is smaller than t-test table $(2.056)$ and $p$-value $(0.603)$ is bigger than the significance level $(0.05)$. As a consequence, we come to conclude that there was no significant difference between the pre-test and post-test in listening sub-skills.

Table 1: Comparison of The Two Groups T-Test Results on the Pre-Posttests Scores in Listening sub-skills

\begin{tabular}{|l|l|l|l|l|l|l|l|l|l|}
\hline Groups & $\begin{array}{l}\text { Type of } \\
\text { tests }\end{array}$ & Means & $\begin{array}{l}\text { Mean } \\
\text { difference }\end{array}$ & $\begin{array}{l}\text { std. } \\
\text { Deviation }\end{array}$ & $\begin{array}{l}\text { Correlation } \\
\text { value }\end{array}$ & $\begin{array}{l}p \text { - } \\
\text { value }\end{array}$ & $\begin{array}{l}\text { Achieved } \\
\text { table }\end{array}$ & & sig. \\
\end{tabular}




\begin{tabular}{|c|c|c|c|c|c|c|c|c|c|c|}
\hline \multirow[t]{2}{*}{ Experimental } & pre-test & 6.74 & \multirow[b]{2}{*}{-1.323} & 1.570 & \multirow[t]{2}{*}{0.601} & \multirow[t]{2}{*}{0.000} & \multirow[t]{2}{*}{4.936} & \multirow[t]{2}{*}{2.042} & \multirow[t]{2}{*}{0.000} & \multirow[t]{2}{*}{ sig. } \\
\hline & post-test & 8.06 & & 1.750 & & & & & & \\
\hline \multirow[t]{2}{*}{ Control } & pre-test & 7.50 & \multirow[b]{2}{*}{0.31} & 2.717 & \multirow[t]{2}{*}{0.320} & \multirow[t]{2}{*}{0.111} & \multirow[t]{2}{*}{0.527} & \multirow[t]{2}{*}{2.056} & \multirow[t]{2}{*}{0.603} & not \\
\hline & post-test & 7.19 & & 2.367 & & & & & & sig. \\
\hline
\end{tabular}

As shown in Table 1, there was a significant difference between the post-test listening skills scores of the experimental group $(\mathrm{t}(4.936)=-1.32 ; p<0.05)$. The experimental group mean score $($ Mean $=8.06$ ) was higher than the control group mean score (Mean = 7.19). It means that the more the standard deviation is closer to means, the more the variable (in this case MALL) was effective on developing listening sub-skills. Considering the standard deviation for pre-test (1.570) is closer to means (6.74) and $p$-value is smaller than 0.05 ; it shows the value and significance effects of MALL on experimental group. Comparing the experimental group pre-test mean score (6.74) to the control group pre-test mean score (7.50), indicates control group outperformance over experimental group. However, comparing the experimental group post-test mean score (8.06) to the control group post-test mean score (7.19), indicates the outperformance of experimental group over the control group. At the start of the study, the pre-test in listening sub-skills suggested no relevant differences between the two groups; therefore, it is reasonable to suppose that any post-test differences would be a consequence of the treatment. So the proposed hypothesis is accepted.

\section{Conclusions:}

The main focus of this paper was on students' use of their mobile devices in EFL teaching and learning context in order to improve their listening sub-skills. Comparing the two groups, it can be claimed that mobile learning devices were effective in developing the students' listening sub-skills. The paper concluded that mobile assisted language learning was effective in developing Al iraqia university EFL students' listening skills. Moreover, the use of mobile devices can be a very useful way for learners to improve their abilities of listening skills. Therefore, the use of mobile technology does not lead to harm but improves the students' language learning particularly listening skills.

\section{References}

[1] •Al-Musalli, A., 2001. Listening Comprehension as a Complex Skill and the Sub-skills Involved in the Process of Speech Perception. Journal of the document center and Humanity Studies, 13. pp. 35-84.

[2] -AL-Qudaimi, K., 2013. Mobile-Assisted Language Learning: A Literature Review. 1-15 Retrieved January 29, 2016 from ://ubimotion.iwi.uni- hannover.de/lv/seminar

[3] •Anderson, A., \& Lynch, T., 2003. Listening (11th ed.). Oxford: Oxford University Press.

[4] -Attewell, J., 2005. Mobile technology and learning: A technology update and m-learning project summary. Technology Enhanced Learning Research Centre. pp. 1-19. Retrieved October 28, 2016 from http://ubimotion.iwi.uni- hannover.de/lv/seminar_ws05_06/files/10_Riemer/literatur/Attewell2004.pdf

[5] -Azar, A. S. and Nasiri, H., 2014. Learners' Attitudes toward the Effectiveness of Mobile Assisted Language Learning (MALL) in L2 Listening Comprehension. Procedia - Social and Behavioral Sciences 98, 1836 - 1843.

[6] Begum, R., 2011. Prospect for Cell Phone as Instructional Tools in the EFL Classroom: A Case Study of Jahangirnagar University, Bangladesh.

[7] -Caudill, J. G., 2007. The growth of m-learning and the growth of mobile computing: Parallel developments. International Review of Research in Open and Distance Learning, 8(2), 1-160.

[8] -Cherian, E. J., Williams, P., 2008. Mobile learning: The beginning of the end of classroom learning. Paper presented at The World Congress on Engineering and Computer Science WCECS 2008, October 22-24, San Francisco. Cambridge University Press.

[9] - Chinnery, G. M., 2006. Emerging technologies, going to the MALL: Mobile assisted language learning. Language Learning \& Technology 10(1), pp. 9-16.

[10] -Good, C. V., 1973. Dictionary of Education, 3rd addition. Mc Graw-Hill Book company.

[11] -Goundar, S., 2011. What is the Potential Impact of Using Mobile Devices in Education? Using Mobile Devices in Education, Proceedings of SIG GlobDev Fourth Annual Workshop, Shanghai, China - December 3, 2011, pp.1-30.

[12] •Helgesen, M., 2003. 'Listening', in Nunan, D. (ed.), Practical English Language

[13] 'Kennedy, C., \& Levy, M., 2008. L'italiano al telefonino: Using SMS to support beginners' language learning. ReCALL Journal, 20(3), 315-330. 
[14] •Mehta K. N. 2012. Mobile Phone Technology in English Teaching: Causes \& Concerns. by Naveen K. Mehta Mobile Phone Technology in English Teaching: Causes \& Concerns. MJAL, 4(2), pp. 82-92.

[15] •Robinson, J. (2010). Understanding vocabulary in context. Douglas College. Learning Centre.

[16] -Schmitt, N. (ed.). 2002. An Introduction to Applied Linguistics, Hodder Arnold, A member of the Hodder Headline Group, London.

[17] -Sevari, K., 2012. The role of Mobile Phones in English and instruction of classroom materials. Advanced in Education, 1(1), 19-22. Teaching. New York: McGraw-Hill.

[18] •Thornton, P. and Houser, C., 2005. Using mobile phones in English education in Japan. Journal of Computer Assisted Learning 21, 217-228.

[19] •Traxler, J., 2005. Defining Mobile Learning. IADIS International Conference Mobile Learning. Pp. 261-266.

\section{Appendices}

\section{Appendix (A)}

Pre-test in Listening Sub-Skills from "Q: Skills for Success"

Experimental and Control Groups (15 Marks)

Instructions: This test aims at assessing students' listening sub-skills.

a) Before listening to the talk read the questions. (1 minute)

b) You will now listen to the talk.

c) Now listen to the talk and answer these questions. You may take notes.

Draw a circle around the most correct letter option. Choose only one option. Marks are equally distributed. Each question is allocated (1 Mark).

What percentage of U.S. high school students cheat? (General understanding: specific information)

25\%b. $75 \%$ c. $50 \%$ d. $100 \%$

According to TV news presenter, some experts say "students are not learning as much as they should." What do you conclude from this speech? (Inferring: Identifying attitude)

Students cheat these days

Students study hard these days

Students study through technology these days

Students do not work hard in the past

How is Ms. Smith's opinion about using the Internet? (Identifying different opinions)

She does not allow students to use the Internet

She thinks using it disadvantageous

The Internet is the cause of cheating

She thinks using it hurting students

What do you assume from Ms. Smith's sentence "We need to do something here, Don."?(Assumption)

Put cameras away

Put cameras just in her classroom

Put cameras in all of classrooms

Put cameras in Mr. Quinn's classroom

What does Mr. Quinn mean when he said that his students are honest? (Implied meaning)

It is OK to copy from the Internet

He doesn't think his students cheat 
He thinks that his students know cheating is allowed

He doesn't allow cheating if they try

What is the main idea of the TV news report? (General Understanding: main idea)

Honesty in schools c. using technology in schools

Cheating in schools $d$. trust students

Choose a topic for this listening passage? (General understanding: Identifying topic of the listening)

Technologyb. honestyc. dishonesty d. prevent technology

What does "illegal" mean in this listening passage? (Guessing the meaning of unknown words in context)

OK sometimes

Not OK sometimes

Not allowed by law

Quite OK

This is the best summary of the main idea of the TV news report: (Summarizing: deduce meaning)

Many countries have problems with cheating. Some universities in China stop wireless phone messages, so students can't send text messages.

Cheating is a problem in many schools. New technology makes it easier to cheat. Schools and teachers are thinking of ways to stop cheating.

Teachers believe their students are honest, so they feel upset when students cheat. Students who cheat receive a zero on their work.

What is the purpose of the TV news program? (General understanding: Purpose of the speaker)

Give advice to teachers $\mathrm{c}$. inform people about students' cheating

give advice to managersd. let students afraid of teachers

What are some of the ways the students cheat? (General understanding: Identifying details)

Buy test questions

Someone else takes the exam

Through technology

Stealing tests from teachers

The government of one of the African countries cancelled about $25 \%$ of test scores, why? (General understanding: Supporting ideas)

The students cheated

The test was revealed

The test was difficult

The test was easy

According to the reporter, what would be the next week's program about? (prediction of what will be happening in advance)

University teachers' opinions about cheating

School teachers' opinions about cheating

University students' opinions about cheating

School students' opinions about cheating 
What can be inferred from Ms. Smith's speech "Students need to learn that school isn't just about grades."?(Inferring: speaker's tone of voice)

They need to just pass the exams

Passing the exams with high marks is important

Grades are not important

Passing the exams by cheating is important

What does the man mean? "The Internet is really helpful and easy to use...but I guess it can create problems sometimes." (Idiomatic expressions)

He is worried about students

He is worried about cheating

$\mathrm{He}$ is worried about copying from websites

He is worried about teachers

Appendix (B)

Table 1 Experimental \& Control Groups Students' Pretests in Listening Sub-skills Results

\begin{tabular}{|c|c|c|}
\hline Students $\neq$ & $\begin{array}{l}\text { Experimental } \\
\text { Group Pretest } \\
\text { Results (out of } \\
15 \text { ) }\end{array}$ & $\begin{array}{l}\text { Control Group } \\
\text { Pretest Results } \\
\text { (out of 15) }\end{array}$ \\
\hline 1 & 5 & 11 \\
\hline 2 & 4 & 6 \\
\hline 3 & 6 & 7 \\
\hline 4 & 5 & 8 \\
\hline 5 & 9 & 7 \\
\hline 6 & 6 & 3 \\
\hline 7 & 8 & 11 \\
\hline 8 & 4 & 8 \\
\hline 9 & 7 & 10 \\
\hline 10 & 5 & 11 \\
\hline 11 & 6 & 11 \\
\hline 12 & 8 & 5 \\
\hline 13 & 5 & 9 \\
\hline 14 & 5 & 9 \\
\hline 15 & 7 & 7 \\
\hline 16 & 6 & 7 \\
\hline 17 & 7 & 5 \\
\hline 18 & 7 & 8 \\
\hline 19 & 6 & 3 \\
\hline 20 & 5 & 4 \\
\hline 21 & 7 & 3 \\
\hline 22 & 6 & 6 \\
\hline 23 & 8 & 7 \\
\hline 24 & 7 & 9 \\
\hline 25 & 7 & 13 \\
\hline
\end{tabular}




\begin{tabular}{|l|l|l|}
\hline 26 & 9 & 7 \\
\hline 27 & 9 & \\
\hline 28 & 9 & \\
\hline 29 & 9 & \\
\hline 30 & 8 & \\
\hline 31 & 9 & \\
\hline
\end{tabular}

\section{Appendix (C)}

Table 2 Experimental \& Control Groups Students' Posttests in Listening Sub-skills Results

\begin{tabular}{|c|c|c|}
\hline $\begin{array}{l}\text { Students } \\
\neq\end{array}$ & $\begin{array}{l}\text { Experimental } \\
\text { Group Posttest } \\
\text { Results (out of } \\
\text { 15) }\end{array}$ & $\begin{array}{l}\text { Control } \\
\text { Group } \\
\text { Posttest } \\
\text { Results } \\
\text { (out of } \\
15 \text { ) } \\
\end{array}$ \\
\hline 1 & 7 & 6 \\
\hline 2 & 7 & 8 \\
\hline 3 & 9 & 7 \\
\hline 4 & 7 & 11 \\
\hline 5 & 10 & 10 \\
\hline 6 & 6 & 8 \\
\hline 7 & 7 & 7 \\
\hline 8 & 4 & 3 \\
\hline 9 & 9 & 8 \\
\hline 10 & 8 & 9 \\
\hline 11 & 7 & 6 \\
\hline 12 & 8 & 7 \\
\hline 13 & 7 & 7 \\
\hline 14 & 7 & 12 \\
\hline 15 & 10 & 5 \\
\hline 16 & 8 & 4 \\
\hline 17 & 10 & 9 \\
\hline 18 & 7 & 6 \\
\hline 19 & 8 & 4 \\
\hline 20 & 7 & 4 \\
\hline 21 & 8 & 5 \\
\hline 22 & 8 & 7 \\
\hline 23 & 4 & 7 \\
\hline 24 & 9 & 6 \\
\hline 25 & 8 & 11 \\
\hline 26 & 10 & 10 \\
\hline 27 & 8 & \\
\hline 28 & 11 & \\
\hline 29 & 11 & \\
\hline 30 & 9 & \\
\hline 31 & 11 & \\
\hline
\end{tabular}

